\title{
Relevant Drivers for Customers ' Churn and Retention Decision in the Nigerian Mobile Telecommunication Industry
}

\author{
- Sulaimon Olanrewaju Adebiyi, Emmanuel Olateju Oyatoye, Bilqis Bolanle \\ Amole
}

\begin{abstract}
The need for better support marketing decision on customers who are likely to leave a service provider for a competitor is very essential to the survival of most telecommunication firms. The application of logistic regression to the study of customer churn and retention decision in the Nigerian telecommunication industry falls into proactive methods, which helps in a better understanding of the needs of subscribers, to be able to predict their churn and retention decision in the industry and enhance better marketing strategies with a research driven policy guide for the operators in the industry. The purpose of this study is to ascertain the relevant drivers of customers churn and retention in the growing Nigerian mobile telecommunication industry. Considering this issue, the logistic regression models have been used as the evaluating method. Four hundred and eight questionnaires have been used in this study. The population of this questionnaire consists of subscribers of mobile telecommunication in the six selected campuses of higher institution of learning in Lagos-state, Nigeria. The data collected was analysed by STATA 12 software. The results showed that the coefficients of mobile number portability (MNP) services and dubious promotions are positive and significant. Furthermore, low coverage and unwanted calls and SMS are positive and significant. This implies that the better the availability of MNP services, the greater the likelihood of customers' churn. More so, an increase in quality of calls provided by mobile telecom firms will increase the likelihood of customers' loyalty by retention. The study recommends strong institutional measures for the overhaul of mobile services provision towards an improved service delivery in Nigeria.
\end{abstract}

Keywords: Drivers, churn, retention, telecommunication, mobile number portability, logistic regression JEL Classification: C21, L10, M2, M31

\section{INTRODUCTION}

Telecommunication seems to be an inseparable part of our everyday life, as mobile phone phones are now playing a great role in enhancing effective communicate both at individual and at organisational level, and from one place to another place. The importance of communication to human life cannot be overemphasized, as it has been observed that an average human being keeps mobile phone at arm's length all the time, even while sleeping (Oyatoye, Adebiyi \& Amole, 2015). The mobile phone is not only used for making calls, among many other functions, it is used for communicating through text-messages, multi-media messages, social media as well as internet facilities. The opportunities that lie in the telecommunication market seem endless and 
the growing demand for mobile telephony systems is creating a worldwide market. Hence, actors in this industry are seeking the most profitable markets throughout the world (Hossain \& Suchy, 2013).

IBM Corporation (2010) has described churn as the process of customer turnover (switching or termination of contract with network providers) which is not restricted to a telecommunication market. It occurs wherever stiff competition provides incentives for customers to switch providers, especially with mobile number portability (MNP) implementation, which gives a legal backing to customers' switching (porting) behaviour from one service provider to the other without losing their original number which might have even been the barrier in switching out-rightly before the period MNP was implemented, for the fear of losing contact with those who know the old contact number or those on the same network service provider (Oyatoye, Adebiyi \& Amole, 2015). However, it should be noted that churn is more familiar in the telecommunication industry as this was not experienced in Nigeria before 2001. Thirteen years later, four major players struggle to secure the patronage of customers from the same market in providing the essential service of effective communication and the implementation of MNP. This empowers subscribers to switch their network providers without losing their original/known number. Therefore, churn has become an issue of major concern for all stakeholders, as it affects firms' revenues, profitability, and survival as well as questions quality service delivery in competition, which in turn, enhances satisfaction of subscribers.

Customer churn (often referred to as customer attrition in other industries) in mobile telecommunication is the movement of subscribers from one service provider to another. It is the propensity of customers to cease doing business with an organisation. Customer churn, sometimes known as customer attrition or customer turnover, is the loss of existing subscribers to another company or service provider (Kerdprasop, Kongchai \& Kerdprasop, 2013). Business sectors consider customer churn seriously because the cost of retaining current customers has been found from research to be much lower than acquiring new ones (Syam \& Hess, 2006).

Many subscribers frequently churn one provider to another in search of better rates or services (Kolajo \& Adeyemo, 2012). Thus, as it applies to this study, customer churn is the loss of existing subscribers to a competitor or shift of preference to other competitors (Jie \& Xu, 2009). This phenomenon when it does occur, has the potential to result in considerable loss or profit to a company. As such, the prevention of customer churn, especially the profitable ones is central to the survival of businesses.

Losing customers or customer churn has been suggested to be one of the problems that many firms may face in the 21st century (Chih-Fong \& Yu-Hsin, 2009). This is because, churning of good customers has irrecoverable disadvantages for a famous company. This study examines the relevant customer's churn drivers (mobile phone subscribers), churn rate and present the motivation for churning among service provider by subscribers. In fact, customer's churn, which is the decision of customers to terminate the relationship with a provider, is a major concern for telecommunication firms in most countries in the world (Portela \& Menezes, 2011). Thus, if a customer terminates a membership agreement with one telecommunication company in this era of MNP and become subscriber of another competitor while he/she maintains the original number, this subscriber is called a churn customer. 
In fact, considerable increase of business competition in the Nigerian mobile (GSM) telecommunications industry in the last eight years that the Etisalat service provider joined the Nigerian telecommunication market. Besides, the implementation of mobile number portability (MNP) in 2013 has greatly increased the switch from one service provider to another. These have also increased the churn rate of customers and seriously affected the financial performance of the telecommunication firms and costs of implementing their promotional strategies to fight the competition. This has led several researches to note that customer churn is the main reason of loss of profits in the telecommunication industry, as signaled by losses in current and potential revenues, marketing costs, brand image, and so on (Ahna, Hana \& Lee, 2006; Qian, Jiang \& Tsui, 2006).

Churn behaviour is a common problem faced by telecom companies as it reduces the revenue, profitability, and damages the brand image of the business (Adebiyi, Oyatoye, \& Kuye, 2015). Apart from these, the privatisation/liberalisation of the Nigeria telecommunication market in 2001 has increased the number of operators from one to five and equally increased competition. This has afforded customers to choose among service options, the service provider that will provide the best service. Lu (2002) notes that customers exercise their right to choose among the existing providers and thereby switch (port) from one company (operator) to another. Moreover, MNP gives the legal right to dissatisfied customer to switch (port) to any other competitors without losing the original number that the service subscribers is identified with.

For his part, Geppert (2003) defines churning as the movement of customers from one service provider to another in search of better and cheaper products and services. In relation to this, Richeldi and Perrucci (2002) contend that customers become churners when they suspend their subscription or spend less and/or move to the next competitor.

Churning behaviour is synonymous to customer turnover. As Neslin, Sunil, Wagner, Junxiang and Mason (2006) notes that customer churn is "the propensity of the customer to cease doing business with a company in a given period of time". In this context, Ghosh (2007) introduced the cross-buying concept, while Eppen, Ward, Ward and Kipp (1991), argued that customers who signed up for more than one service within a single company tend to be more loyal than those who contract for one service. This cross-buying behaviour increases the loyalty and reduces churn attitude. Moreover, churn management represents a proactive approach to retain customers. It involves identifying likely churners based on demographic and behavioural customer data, targeting these customers with a retention campaigns and other factors (Neslin, Gupta, Kamakura, Lu \& Mason, 2006). This study focuses majorly on pre-paid services in the Nigerian telecommunication industry, since the issue of churn is dominant to this group, especially with MNP policy implementation in Nigeria.

Consequently, the study provides answer to the research question, which seeks to understand, what are the major drivers of customers churn and retention in the Nigeria mobile telecommunication industry? 


\section{LITERATURE REVIEW}

\subsection{Customer Churn}

In this study, we rely on the operational definition of churn as given by Alberts (2006), churn occurs when a customer has permanently stopped using/recharging his SIM-card as early as possible. It is also the rate of movement of subscriber within a system (GSM operators). Thus, churn situation is when a number of customers switch/port their preferences among network providers.

According to Modisette (1999), churn can be categorised into three types;

1. Involuntary churn: This occurs when subscribers fail to pay for service and as a result the provider terminates service. Termination of service due to theft or fraudulent usage is also classified as involuntary churn.

2. Unavoidable churn: This occurs when a customer dies or moves or is otherwise permanently removed from the marketplace, travels outside the country without roaming, and possibly permanently relocates to places outside the outside network coverage.

3. Voluntary churn: Termination of service relationship by the customer, leaving one service operator for another because of better value or dissatisfaction with current service provider.

In reality, it is most unlikely that a service provider could differentiate unavoidable and voluntary churn and predict them separately through secondary data (database) of the telecom operators. However, questions may be asked through primary data instruments (questionnaire or interviews) to get information on the reasons or motives for a subscriber to make voluntary or involuntary churn. This rather can be analysed using logistic regression.

\subsection{Churn Drivers}

According to Hamelin, Nassali and Harcar (2010), a number of researchers and academics have studied factors that may cause churn. However, it is important to investigate why customers are leaving before selecting the appropriate churn-reduction mechanisms. For Fox and Poje (2002), a better price is the main factor but not the "prevailing reason". In fact, as it has been observed, offering a lower price does not necessarily mean higher customer loyalty. They also reveal that customers churn to the competitor who best matches their needs in terms of service features, technology, and service quality. The probability that a subscriber will change the actual carrier depends on the satisfaction level reached in addition to factors relating to service attributes, which include call quality, tariff level, handsets, brand image, income and other relevant factors. In addition to these service attributes, Kumar (2007) has indicated that the transparency level of any company is highly associated with customer satisfaction. When a specific firm adopts transparent marketing strategies, communicates transparent tariffs and makes information available, it increases the customer confidence and satisfaction. Geppert (2003) summarises in his article the most important factors which explain the churn attitude:

1. Price: Higher prices than those of competitors, changing fees constantly or lack of transparency regarding services and products provide customers with high incentives to switch. 
2. Customer service quality: The manners in with which services and products are delivered to customers play a crucial role in their satisfaction. Lack of reliability, responsiveness and availability of staff would drive customers to terminate the relationship with the service provider.

3. Payment Loopholes: Customers may attempt to "game the system" by generating high usage volumes and avoiding payment by constantly churning to the next competitor."

4. Lack of responsiveness: Lack of response to customer complaints or no answer to their problems may lead to poor service delivery and therefore, to ending the contract.

5. Privacy concerns: Any attempt to use personal information for specific purposes or to divulge it to other parties could break the relationship. Companies have the responsibility and the duty to keep all information they have about their customer secret and not to use it for the purposes of communication or telemarketing.

6. Lack of features: Subscribers are always looking for innovative and original products. Customers will churn if their actual carrier is unable to provide them with what they need, when and where they need it.

7. New technology or new products introduced by competitors: Customers could switch companies if the next competitor introduces new products, launches new services or brings to the market new technology that has never been used before.

8. New competitor enters the market: A new service provider in the market offering interesting incentives and attractive service packages may cause some customers to churn from one service provider to a new one.

9. Billing or services disputes: Continuous billing errors, incorrect payment or disputes about services can lead to customer churning.

Another important point worth noting as a churn driver is the absence of switching costs when a customer makes a decision to cease business with its current telecom operator. Switching costs are barriers which prevent subscribers from changing a service provider. Without these barriers, churners can conveniently switch between various service providers. Furthermore, the introduction of MNP in the telecom industry enhances the ability of mobile phone subscribers to switch from one service provider to another without losing their original numbers that people identify them with.

A churn implies large costs for firms and for a telecommunication network service provider to convince a subscriber to switch to its product or service; it needs to make marketing efforts (promotional mix). The longer a customer has a relationship with a network providers, the more profit is generated for the later through recharges and positive words of mouth (referrals). Therefore, a network provider must strike a balance between maximising the number of customers it has and minimising (marketing) costs by managing churn. To achieve this, the network provider needs to have a clear picture of and understand the dynamics of subscribers' behaviour present in the market. Hence, the need to understand which variable(s) motivates subscribers to switch product/services to other competitors as well as what influences their decision to stay with a service provider. 
Furthermore, Tsai and Lu (2009) noted that in today's competitive market, many companies are have realized the importance of the customer-oriented business strategy for sustaining their competitive edge and maintaining a stable profit level. In other words, companies mainly rely on the income, which comes from customers. However, to create and retain customers is difficult and costly in term of marketing. As acquisition of new subscriber involve new account setup, advertising and promotional expenses which can add up to several times the cost of efforts and resources that may enable the firms to retain a customer (Keaveney, 1995). It is becoming an industry-wide belief that the best core marketing strategy for the future is to retain existing customers and avoid customer churn (Kim, Park \& Jeong, 2004; Kim \& Yoon, 2004).

Burez and Van den Poel (2007) indicated two types of targeted approaches to managing customer churn: reactive and proactive. When a company adopts a reactive approach, it waits until customers ask the company to cancel their service relationship. In this situation, the company will offer the customer an incentive to stay. On the other hand, when a company adopts a proactive approach, it tries to identify customers who are likely to churn before they do so. The company then provides special programmes or incentives for these customers to keep the customers from churning. Targeted proactive programmes have potential advantages of having lower incentive costs. However, these systems may be very wasteful if churn predictions are inaccurate because companies are wasting incentives (money) on customers who will not churn. Therefore, it is important to build a customer-churn prediction model as accurately as possible (Burez \& Van den Poel, 2007; Van den Poel \& Larivie're, 2004).

Consequently, the application of logistic regression to the study of customer churn and retention decision in the Nigerian telecommunication industry falls into proactive methods. This makes for a better understanding of the needs of subscribers to predict customer churn and retention in the industry in order to enhance better marketing strategies and provide research driven policy guide for the operators in their quest for the optimal development of the industry.

\subsection{The churn prediction models}

Hadden, Tiwari, Roy and Ruta (2006) observed that many techniques have emerged for predicting a required outcome. The methods which are most frequently used in research, therefore, have been recognised as neural networks, classification trees and regression (Van Den Poel, \& Lariviere, 2004; Au, Chan \& Yao, 2003; Boone \& Roehm, 2002). Therefore, Hadden et al, (2006) pointed out suitability of these technologies for predicting customer churn using the complaints data previously mentioned. In their study, each model was created for each of the chosen technique (Linear Regression, Regression Tree and Neural Network). The models were constructed using the same training dataset. The training dataset consists of 202 customers with a 50: 50 ratio of churners and non-churners. The regression tree and neural network models were created using Matlab. The Matlab is a high-level language and interactive environment that enables its users to perform rigorous tasks much faster than they can be done by using conventional programming languages. It has many pre-written toolboxes that can be used with minimum training to perform experiments by using many advanced technologies. Some examples of toolboxes available include neural networks, statistics, fuzzy logic and signal processing. Hadden, et al, (2006) also used Matlab with the neural network toolbox and the statistical toolbox. However, 
many studies have not collected primary data from subscribers who used the services on a daily basis, and used a logistic regression model to ascertain the relevant drivers of churn and retention decision, especially in the Nigerian growing mobile telecommunication market.

\subsection{Customer Retention}

The customer retention is a part of customer relationship management (CRM). According to Payne (2006), CRM is a business approach that seeks to create and develop relationships with carefully targeted subscribers in order to improve the value of customers and corporate profitability so as to maximise shareholder value. Thus, an effort by a telecommunication organisation to improve customer value will also assist in ensuring their essence of been in business, which, of course, is to make profit. Hennig-Thurau and Hansen (2000) argued that relationship marketing has become one of the most prosperous branches of marketing theory and the most important management issues for the business community in recent times.

The argument for the customer retention is relatively straightforward as it is more economical to keep an existing customer than to acquire new ones. According to some studies, acquiring new customers is calculated as being five times more costly than the expenses of retaining an existing customer. The costs of obtaining customers to replace those who have been lost are high, because the expenses of acquiring ones are incurred only at the beginning stages of the commercial relationship (Hurley, 2004; Reichheld \& Kenny, 1990). In addition, long-term customers buy more, and if satisfied, may generate positive word-of-mouth promotion for the company at relatively no cost to the firm. Finally, long-term customers take less of the company's time, and are less sensitive to price changes (Healy, 1999).

Although many companies recognise the value and importance of the customer retention in general, only a considerable few understand the economics of retention in their own business (Kotler, 2003; Payne, 2006). Companies can clearly benefit from increasing the lifetime spending of customers. Most companies, however, channel a significant amount of resources on attracting and acquiring new customers, instead of keeping the existing ones. As it is perceived in the Nigeria telecommunication industry, all network providers (GSM companies) focus on similar promotional activities almost at the same time. It is generally believed that once a customer is acquired, keeping the customer is simple through superior products and services (Payne 2006). As Van-Den-Poel and Lariviere (2004) summarised, the economic value of customer retention are as follows:

1. lowering the need to seek new and potentially risky customers, which allows more focus on demands of an existing customers;

2. long-term customers tend to buy more;

3. positive word of mouth from satisfied customers is a good way for new customers' acquisition;

4. long-term customers are less costly to serve due to a larger database of their demands;

5. long-term customers are less sensitive to competitors' marketing activities;

6. losing customers results in less sales and an increased need to attract new customers, which is five to six times more expensive than the money spent on retention of an existing customers; 
7. many times, people tend to share negative than positive service experience with friends, this may result in negative image of the company among possible future customers.

Therefore, the customer retention rates are receiving an increased attention from academic market researchers as one of the most important metrics in customer relationship management (Reinartz \& Kumar, 2002). In this regards, Benner and Tushman (2003) noted that during the periods of incremental changes in stable tenure of industries, ability to minimise the number of defected clients is becoming crucial. Similarly, Bain (1996) indicated that reducing defection rates by $5 \%$, boosted profits, from $25 \%$ to $85 \%$, depending on industry. Similarly, Reichheld (1996) revealed that customers become not only significantly more profitable over time, but they are most likely to bring new clients to the company (referral), using most effective means of advertisement at cheap/no cost to the organisation. This contributes in boosting the profit of the country. In order to retain customers more effectively, telecommunication companies must understand subscribers and market services, which motivate them to remain with the current service provider and not switch (port) to other competitors who render similar or same service.

\section{RESEARCH METHODS}

This study adopted quantitative methods which are generally associated with the philosophical traditions of positivism. A cross sectional survey with the aid of a structured questionnaire was used to address the problem of this study, since the reasons to churn or retain a network SIM can be best explained by the subscribers who have received the service or have been informed by those who use the services. The total sample for the study consists of 480 mobile phone subscribers/customers in the selected tertiary institutions in Lagos. Lagos is divided into five divisions namely: Ikeja, Badagry, Lagos, Ikorodu and Epe division. A multi-stage sampling design was used to select six out of eleven tertiary institutions in Lagos state. The first stage was the selection of all the tertiary institutions in Lagos state irrespective of their ownership structure as shown in the Table 1 .

Tab. 1 - Tertiary Institutions in Lagos divisions and their ownership

\begin{tabular}{|l|l|l|l|}
\hline \multirow{2}{*}{ Divisions } & \multicolumn{3}{|c|}{ Ownership Structure } \\
\cline { 2 - 4 } & \multirow{2}{*}{ Federal } & \multicolumn{1}{|c|}{ State } & \multicolumn{1}{c|}{ Private } \\
\hline \multirow{2}{*}{ Ikeja } & - & & $\begin{array}{l}\text { (i) Lagos City Polytech- } \\
\text { nic, Ikeja. } \\
\text { (ii) Wolex Polytechnic, } \\
\text { Ikeja. }\end{array}$ \\
\hline & - & - & $\begin{array}{l}\text { (i) Lagos state Univer- } \\
\text { sity, Ojo. } \\
\text { (ii) Adeniran Ogunsanya } \\
\text { College of Education. } \\
\text { Ijanikin }\end{array}$ \\
\hline
\end{tabular}




\begin{tabular}{|l|l|l|l|}
\hline \multirow{2}{*}{ Lagos } & $\begin{array}{l}\text { (i) University of Lagos, } \\
\text { Akoka } \\
\text { (ii) Yaba College of } \\
\text { Technology. Yaba } \\
\text { (iii) Federal College of } \\
\text { Education (Technical). } \\
\text { Akoka }\end{array}$ & & \\
\hline Ikorodu & - & $\begin{array}{l}\text { (i) Lagos State Polytech- } \\
\text { nic. Ikorodu. }\end{array}$ & $\begin{array}{l}\text { (i) Caleb University, } \\
\text { Imota }\end{array}$ \\
\hline Epe & \multicolumn{1}{c|}{$\begin{array}{l}\text { (i) Michael Otedola Col- } \\
\text { lege of Primary Educa- } \\
\text { tion, Epe. }\end{array}$} & $\begin{array}{l}\text { (i) Pan-Atlantic Univer- } \\
\text { sity, Lekki }\end{array}$ \\
\hline
\end{tabular}

Source: Authors` Compiled, (2014).

In the second stage, six tertiary institutions were selected from the earlier identified eleven across five divisions in the state. The selected institutions are presented Table 2.

Tab. 2 - Sampled Tertiary Institutions in Lagos divisions and their ownership

\begin{tabular}{|c|c|c|c|}
\hline \multirow{2}{*}{ Divisions } & \multicolumn{3}{|c|}{ Ownership Structure } \\
\hline & Federal & State & Private \\
\hline Ikeja & - & - & $\begin{array}{l}\text { (i)Wolex Polytechnic, } \\
\text { Ikeja. }\end{array}$ \\
\hline Badagry & - & $\begin{array}{l}\text { (i) Lagos state Univer- } \\
\text { sity, Ojo. }\end{array}$ & - \\
\hline Lagos & $\begin{array}{l}\text { (i) University of Lagos, } \\
\text { Akoka } \\
\text { (ii) Yaba College of } \\
\text { Technology. Yaba }\end{array}$ & - & - \\
\hline Ikorodu & - & - & $\begin{array}{l}\text { (i) Caleb University, } \\
\text { Imota }\end{array}$ \\
\hline Epe & - & $\begin{array}{l}\text { (i) Michael Otedola Col- } \\
\text { lege of Primary Educa- } \\
\text { tion, Epe. }\end{array}$ & - \\
\hline
\end{tabular}

Source: Authors`compiled, (2014).

The respondents were of different age groups, incomes, educational background, information needs and so on. Lagos was chosen because it is the economic nerve center of Nigeria (commercial capital), with the highest number of GSM subscribers (Adeleke \& Aminu, 2012). The sample consists of the customers of the four major GSM companies in the selected area. These include MTN, Airtel, Glo, and Etisalat. The operators account for over 85 percent of mobile subscriptions in the country (Pyramid Research, 2010). In a bid to collect quality data that reflect subscribers` opinion on reason(s) for their decision on churning or staying with a mobile network provider, convenience sampling technique was employed in selecting the respondents 
who were administered with the questionnaires. The sample size of the target group who participated in this study was calculated by using random sampling method of Yamane, (1967) which is expressed as:

$$
n=\frac{N}{\left(1+N(e)^{2}\right.}
$$

where, $\mathrm{n}$ is the sample size, $\mathrm{N}$ is the population size (total number of active subscribers) and $\mathrm{e}$ is the sample error (0.05).

From the above expression, the sample size is obtained as:

$$
n=\frac{133,282,003}{\left(1+133,282,003(0.05)^{2}\right.}=399.99
$$

Eighty copies of the questionnaire were administered in each of the six selected institutions, given a total of 480 subscribers. The sample unit for the study includes students, workers (both academic and non-teaching), literate traders within the campuses, and visitors to the campuses at the time copies of the questionnaire was administered. Out of the 480 questionnaires administered, only 408 were valid for the purpose of the study analysis. To facilitate logistic regression modeling, the dependent variables have been dichotomised into binary form. The customer churn and retention drivers suggested from both the literature and focus group discussion (FGD) conducted by the researchers on GSM subscribers were evaluated. The respondents were asked questions as to ascertain if the drivers can influence their decision to churn or retain a network. The binary questions were the dependent variables of both churn and retention in the logit models, while their satisfaction with service level of the relevant churn and retention drivers, which is based on five in the Likert scale, were the independent variables for the models. The data were analysed using the STATA 12 computer software program. A logistic regression analysis was employed. Logistic regression applies maximum likelihood estimation after transforming the dependent into a logit variable (the natural log of the odds of the dependent occurring or not). In this way, a logistic regression estimates the probability of a certain event occurring. That is, it calculates the changes in the log odds of the dependent variable, not changes in the dependent variable as the Ordinary Least Square regression does.

\section{RESULTS DISCUSSION}

\subsection{The relevant drivers of customers churn in the Nigerian mobile telecommunication industry.}

The results of the logit model to explain relevant drivers of customers' churn are presented in Table 3. The coefficients of MNP and dubious promotions are positive and significant. Furthermore, low coverage and unwanted calls and SMS are positive and significant. This result implies that the higher the availability of MNP services, the greater the likelihood of customers' churn. The positive sign associated with dubious promotions provided by telecommunication firms 
implies that a one grade increase in the level of uncertain promotions activities of the firms is likely to increase the probability of customers' churn by 18.9 percentage points. The statistical significance of dubious promotions is also much higher than the availability of MNP services, an indication that dubious communication activities could rapidly increase churn. Coefficients of low coverage which has a positive sign implies that inability of a telecom firm to spread its bandwidth to cover more areas frequently habituated or occupied by subscribers would increase the likelihood of churn by 17.6 percentage points. Similarly, an increase in unwanted calls and SMS to the subscribers by telecom firms is likely to increase the likelihood of churn by 26.4 percentage points at $1 \%$ level of significance.

Table 3 shows that coefficients of poor message delivery and high tariff by telecom providers are negative and significant at $10 \%$ and $5 \%$ level of significance respectively. The results imply that subscribers are less concerned with poor services related to message delivery and high tariff ceteris paribus. The result is an indication that customers churn is less influenced by tariff rate in Nigeria, on the other hand, drivers within the analysis framework.

Tab. 3 - Logit results on drivers of Customers` churn

\begin{tabular}{|c|c|c|c|}
\hline Explanatory variables & Coefficient & t-ratio & Marginal effects ${ }^{a}$ \\
\hline Lack of quality calls & 0.403 & 1.02 & \\
\hline $\begin{array}{l}\text { Mobile Number Port- } \\
\text { ability }\end{array}$ & 0.442 & $1.99 * *$ & 0.101 \\
\hline Poor message delivery & -0.555 & $-1.66^{*}$ & -0.120 \\
\hline Dubious promotions & 0.793 & $2.92 * * *$ & 0.189 \\
\hline High tariff & -0.958 & $-1.98^{* *}$ & -0.188 \\
\hline Poor connectivity & 0.200 & 0.46 & \\
\hline Low coverage & 0.732 & $1.97 * *$ & 0.176 \\
\hline Inefficient internet & -0.026 & -0.08 & \\
\hline Unwanted calls \& SMS & 1.109 & $3.76^{* * *}$ & 0.264 \\
\hline Constant & -0.897 & $-1.87^{*}$ & \\
\hline Log likelihood & -243.744 & & \\
\hline Number of Obs & 408 & & \\
\hline LR chi(2) 10 & 48.09 & & \\
\hline Prob $>$ chi2 & 0.000 & & \\
\hline Pseudo R2 & 0.089 & & \\
\hline
\end{tabular}

$* * *, * *, * 1 \%, 5 \%, 10 \%$ level of significance

a Marginal effects are shown only for significant coefficients

Source: Analysis output, (2014). 


\subsection{The relevant drivers of customers ' retention in the Nigerian mobile telecommunication industry.}

Table 4 shows the relevant drivers of customers' retention in the Nigeria mobile telecommunication industry. Coefficients of quality of calls, quality of message delivery, efficient internet package and complexity of MNP are positive and significant. The results show that an increase in quality of calls provided by mobile telecom firms would increase the likelihood of customers' loyalty by retention. Similarly, the positive sign associated with the quality of message delivery also indicates that a one-grade improvement in the quality of message delivery would increase the likelihood of loyalty by 17.2 percentage points. In addition, mobile subscribers are more likely to be loyal to their mobile firms if the internet services provided are deemed efficient. Furthermore, the coefficient of complexity of MNP is positive and significant, an indication that subscribers would prefer to retain their mobile service provider if porting to another mobile line is complicated, this corroborated the submission of Adebiyi, Oyatoye and Amole (2015), that MNP was not on the top priority list of factors that make customers to churn network provider in Nigeria. However, how MNP would become complex for a longer time to satisfactorily benefit service providers remains a question for further research.

Tab. 4 - Logit results on drivers of Customers`retention

\begin{tabular}{|c|c|c|c|}
\hline Explanatory variables & Coefficient & t-ratio & Marginal effects ${ }^{a}$ \\
\hline Quality of calls & 0.671 & $1.65^{*}$ & 0.139 \\
\hline Quality of message delivery & 0.711 & $2.00^{* *}$ & 0.172 \\
\hline Frequent promo & -0.027 & -0.12 & \\
\hline Good billing rate/tariff & -0.293 & -0.99 & \\
\hline Easy inter-connectivity & 0.224 & 0.73 & \\
\hline Coverage & -0.050 & -0.17 & \\
\hline Efficient internet package & 0.699 & $2.25^{* *}$ & 0.168 \\
\hline Effective complaint management & 0.325 & 1.11 & \\
\hline Complexity of MNP & 0.746 & $3.27 * * *$ & 0.166 \\
\hline Constant & -0.476 & -0.98 & \\
\hline Log likelihood & -253.107 & & \\
\hline Number of obs & 406 & & \\
\hline LR chi(2) 9 & 26.44 & & \\
\hline Prob $>$ chi 2 & 0.0017 & & \\
\hline Pseudo R2 & 0.0496 & & \\
\hline
\end{tabular}

$* * *, * * * 1 \%, 5 \%, 10 \%$ level of significance

a Marginal effects are shown only for significant coefficients

Source: Analysis output, (2014). 


\section{CONCLUSION AND RECOMMENDATIONS}

The study contributes to a better understanding of factors, which influence customers` churn and retention decision in the Nigerian mobile telecommunication industry. It also identified strategies to be adopted for effective customer retention management, which are necessary for development of the telecommunication industry in Nigeria through the application of logistics regression. The study concluded that the coefficients of MNP and dubious promotions are positive and significant. Furthermore, low coverage and unwanted calls and SMS are positive and significant. This implies that the better the availability of MNP services, the greater the likelihood of customers' churn. The positive sign associated with dubious promotions provided by telecommunication firms implies that a one-grade increase in the level of uncertain promotions activities of the firms is likely to increase the probability of customers' churn by 18.9 percentage points. For the retention drivers, the study concluded that an increase in the quality of calls provided by mobile telecom firms would increase the likelihood of customers' loyalty by retention. Similarly, the positive sign associated with the quality of message delivery also indicates that a one-grade improvement in the quality of message delivery would increase the likelihood of loyalty by 17.2 percentage points. In addition, mobile subscribers are more likely to be loyal to their mobile firms if internet services provided are deemed efficient.

In all, the marginal effects of drivers of customers churn and retention were computed using logistic regression analysis. For retention drivers the marginal effect of customer satisfaction with GSM services after MNP. The result reveals that a unit increase in frequent promotion by network providers will increase customer loyalty to network provider. However, if the billing system changes favourably to customers, it will enhance customer retention. Moreover, easy interconnectivity, coverage, and effective complaint management suggest some marginal effect for percentage increase in customers' satisfaction and enhanced customer retention. There is need for an urgent overhaul of GSM service attributes towards an improved service delivery on the customers churn drivers that are significant to the customer decision for porting from one service provider to the other, in order to enhance customer satisfaction and unbroken patronage.

\section{References}

1. Adebiyi, S. O., Oyatoye, E. O., \& Kuye, O. L (2015). An analytic hierarchy process analysis: Application to subscriber retention decisions in the Nigerian mobile telecommunications industry, International Journal of Management and Economics, 48(1), 63 - 83. http://dx.doi. org/10.1515/ijme-2015-0035

2. Adebiyi, S. O., Oyatoye E. O., \& Amole, B. B. (2015). Determinants of customers` churn decision in the Nigeria telecommunication industry: An analytic hierarchy process approach, International Journal of Economic Behaviour, 5, 81 - 104.

3. Adeleke, A., \& Aminu S. A. (2012). The determinants of customer loyalty in Nigeria's GSM market, International Journal of Business and Social Science, 3(14), 209-222.

4. Ahn, J. H., Han, S. P., \& Lee, Y. S. (2006). Customer churn analysis: Churn determinants and mediation effects of partial defection in the Korean mobile telecommunications service industry. Telecommunications policy, 30(10), 552-568. http://dx.doi.org/10.1016/ j.telpol.2006.09.006 
5. Alberts, L. J. (2006). Churn prediction in the mobile telecommunications industry: An application of Survival Analysis in Data Mining, Unpublished Master Thesis, Maastricht University.

6. Au, W., Chan, C. C. \& Yao, X. (2003). A novel evolutionary data mining algorithm with applications to churn prediction. IEEE transactions on evolutionary computation, 7(6), 532 - 545. http://dx.doi.org/10.1109/tevc.2003.819264

7. Benner, M. J. \& Tushman, M. L. (2003). Exploitation, exploration, and process management: The productivity dilemma revisited, The Academy of Management Review, 28(2), 238-256. http://dx.doi.org/10.2307/30040711

8. Boone, D. S. \& Roehm, M. (2002). Retail segmentation using artificial Neural Networks. International Journal of Research in Marketing, 19, 287-301. http://dx.doi.org/10.1016/s01678116(02)00080-0

9. Burez, J., \& Van den Poel, D. (2007). CRM at a Pay-TV company: using analytical models to reduce customer attrition by targeted marketing for subscription services. Expert Systems with Applications, 32(2), 277-288. http://dx.doi.org/10.1016/j.eswa.2005.11.037

10. Chih-Fong Tsai \& Yu-Hsin Lu (2009). Customers churn prediction by hybrid neural networks. Expert Systems with Applications, 36, 12547-12553. http://dx.doi.org/10.1016/ j.eswa.2009.05.032

11. Eppen, G., Ward A. H., Ward, R., \& Kipp, M. (1991). Bundling - new products, new markets, low risk. Sloan Management Review, 32(4), 7-14. http://dx.doi.org/10.1016/07376782(92)90065-k

12. Fox, M. \& Poje, M. (2002). Churn: are rural telecoms immune? Rural Telecommunications, $21,1-5$.

13. Geppert, C. (2003). Customer churn management: retaining high-margin customers with CRM techniques, 2-3. Retrieved from https://www.amr.kpmg.com/microsite/kpmgme/downloads/ CHURN_02_26final.pdf

14. Ghosh, B. (2007). Cross-buying and customer churning behaviour. Retrieved from www.mgmt. purdue.edu/faculty/sbalacha/crossbuy.pdf.

15. Hadden, J., Tiwari, A., Roy, R \& Ruta, D. (2006). Churn prediction: Does technology matter? World Academy of Science, Engineering and Technology, 16, 193-199.

16. Hamelin, N., Nassali, A \& Harcar, T. (2010). Determining churn drivers in Moroccan telecom sector. Journal of International Business Disciplines, 4(2), 16-34.

17. Healy, T. J. (1999). Why you should retain your customers. America Community Banker, 8(9), 22-26.

18. Hennig-Thurau, T. \& Hansen, U. (2000). Relationship marketing: Gaining competitive advantage through customer satisfaction and customer retention. Germany, Springer.

19. Hossain, M. M. \& Suchy, N. J. (2013). Influence of customer satisfaction on loyalty: a study on mobile telecommunication industry. Journal of Social Sciences, 9 (2), 73 - 80. http://dx.doi. org/10.3844/jssp.2013.73.80

20. Hurley, T. (2004). Managing customer retention in the health and fitness Industry: A Case of Neglect, Irish Marketing Review, 17(1/2). 14 - 34. 
21. IBM Corporation, (2010). Working with telecommunications, Minimizing churn in the telecommunications industry, United States of America.

22. Jie, L. \& Xu, Xu. (2009). A novel model for global customer retention using data mining technology, data mining and knowledge discovery in real life applications, Julio Ponce and Adem Karahoca (ed), 438, I-Tech, Vienna, Austria.

23. Keaveney, S. M. (1995). Customer switching behavior in service industries. Journal of Marketing, 59 (2), 71- 82.

24. Kerdprasop, N., Kongchavi, P. \& Kerdprasop, K. (2013). Constraint mining in business intelligence: a case study of customer churn prediction, International Journal of Multimedia and Ubiquitous Engineering, 8(3), 11-20.

25. Kim, M. K., Park, M. C. \& Jeong, D. H. (2004). The effects of customer satisfaction and switching barrier on customer loyalty in the Korean mobile telecommunication Services. Telecommunications Policy, 28(2), 145-159.

26. Kim, H. S., \& Yoon, C. H. (2004). Determinants of subscriber churn and customer loyalty in the Korean mobile telephony market. Telecommunications Policy, 28, 751-765. http://dx.doi. org/10.1016/j.telpol.2004.05.013

27. Kolajo, T. \& Adeyemo, A. B. (2012). Data mining technique for predicting telecommunications industry customer churn using both descriptive and predictive algorithms. Computing Information Systems \& Development Informatics Journal. 3(2), 27 - 34.

28. Kotler, P. (2003). Marketing Management (11th edition). New Jersey, USA: Prentice-Hall.

29. Kumar, N. (2007). Gaining momentum towards customer centricity. Retrieved from http://www. gtnews.com/article/6953.cfm.

30. Lu, M. H., Madu, C. N., Kuei, C., \& Winokur, D. (1994). Integrating QFD, AHP and benchmarking in strategic marketing. Journal Business \& Industrial Marketing, 9(1), 41 - 50.

31. Modisette, L., (1999). Milking Wireless Churn for Profit, Telecommunications, 73-74.

32. Neslin, S. A., Gupta, S., Kamakura, W., Lu, J. X., \& Mason, C. H. (2006). Defection detection: Measuring and understanding the predictive accuracy of customer churn models. Journal of Marketing Research, 43(2), 204-211. http://dx.doi.org/10.1509/jmkr.43.2.204

33. Oyatoye E. O., Adebiyi S. O \& Amole, B. B. (2015). Modeling switching behaviour of Nigeria global system for mobile communication multiple SIMs Subscribers` using Markov chain analysis, Indiana University Press Journal of Operations Management, 14(1), 7-31.

34. Payne, A. (2006). Handbook of CRM: Achieving excellence in customer management. Great Britain: Butterworth-Heinemann.

35. Portela, S \& Menezes, R. (2011). Detecting customer defections: an application of continuous duration models, Journal of Global Strategic Management, 9, 22-30. http://dx.doi. org/10.20460/jgsm.2011515809

36. Pyramid Research (2010). The impact of mobile services in Nigeria: How mobile technologies are transforming economic and social activities, Abuja, Nigeria. 
37. Qian, Z., W. Jiang, \& Tsui, K. L. (2006). Churn detection via customer profile modeling, International Journal of Production Research, 44 (14), 2913-2933. http://dx.doi.org/10.1080/0020 7540600632240

38. Reichheld, F. F. (1996). The loyalty effect, Boston: Harvard Business School Press.

39. Reichheld, F. F. \& Kenny, D. (1990). The hidden advantages of customer retention, Journal of Retail Banking, 7(4), 19-23.

40. Richeldi, M. \& Perrucci, A. (2002). Churn analysis case study, Retrieved from: http://wwwai.cs.uni-dortmund.de/DOKUMENTE/richeldi_perrucci_2002b.pdf

41. Reinartz, W. J. \& Kumar, V. (2002). The mismanagement of Customer Loyalty, Harvard Business Review, 80 (July), 86-94.

42. Syam, N. B. \& Hess, J. D. (2006). Acquisition versus retention: competitive customer relationship management, Working Paper, University of Houston, Houston, Texas, USA.

43. Tsai, C., \& Lu, Y (2009). Customer churn prediction by hybrid neural networks, Expert Systems with Applications, 36, 12547 - 12553. http://dx.doi.org/10.1016/j.eswa.2009.05.032

44. Van-Den-Poel, D. \& Lariviere, B. (2004). Customer attrition analysis for financial services using proportional hazard models. European Journal of Operational Research, 157, 196-217. http://dx.doi.org/10.1016/s0377-2217(03)00069-9

45. Yamane, T. (1967). Statistics, an introductory analysis (2nd ed.). New York: Harper and Row.

\section{Contact Information:}

Sulaimon Olanrewaju ADEBIYI (Ph. D.)

Business Administration Department,

Fountain University,

PMB 4491. Osogbo, Osun State. Nigeria

E-mail:lanre18april@gmail.com

Emmanuel Olateju OY ATOYE (Ph. D.)

Business Administration Department,

University of Lagos,

Akoka, Lagos. Nigeria.

E-mail:eoyatoye@unilag.edu.ng

Bilqis Bolanle AMOLE (Ph. D.)

Accounting and Business Administration Department,

Distance Learning Institute,

University of Lagos,

P. O. Box 56, Akoka, University of Lagos. Nigeria.

E-mail:bamole@unilag.edu.ng 